Stefan Raychev,

Ph.D., University of Plovdiv Paisii Hilendarski, Bulgaria

email: stefan1@abv.bg

Gergana Dimitrova,

Ph.D., University of Plovdiv Paisii Hilendarski, Bulgaria

ORCID ID, 0000-0003-2304-3372

email: gergana_dim@uni-plovdiv.bg

Blaga Madzhurova,

Ph.D., University of Plovdiv Paisii Hilendarski, Bulgaria

email: bmadzhurova@yahoo.de

Dobrinka Stoyanova,

Ph.D., University of Plovdiv Paisii Hilendarski, Bulgaria

email: bini_stoyanova@abv.bg

Correspondence author: gergana_dim@uni-plovdiv.bg

\title{
INNOVATIONS AS A FACTOR FOR ECONOMIC GROWTH AND LABOR MARKET DEVELOPMENT
}

Abstract. This paper summarises the arguments and counterarguments within the scientific discussion on the effects of R\&D investment on the essential components of the economic development such as economic growth, competitiveness, labour market and inequality reduction. The main purpose of the research is to highlight the position of Bulgaria in the world economy concerning R\&D development. In the article frame, the authors compared the R\&D expenditures dynamics of Bulgaria and the EU28 by the prism of innovations in business and higher education. Systematisation literary sources and approaches for solving the problem indicated that R\&D caused the changes in the job market that led to the necessity to adjust the university system. There is currently a lag. Methodological tools of this research were as follows: the method of processing quantitative data, content and comparative analyses, situational and sectoral analyses, and graphical dynamic analysis. The object of research is the dynamics of investments in innovations in Bulgaria and EU28. The emphasis is placed on the role of research centres, enterprises, clusters and education institutions in R\&D development to assess the level of innovation achieved through $R \& D$. The obtained results of an empirical analysis showed that the cluster approach raised $R \& D$ to a new level and helped to bring universities and business together. Rethinking of the public policies and investing in technology centres will help for the adaptation to the new realities of the labour market. The research results could be useful for employers, high tech research centres and universities. This study is expected to be the base for further studies dedicated to boosting economic competitiveness and social welfare due to the promoting implementation of innovations. (R\&D).

Keywords: competitiveness, economic growth, inequality, innovation, labour market, Research and development

Introduction. The European Commission efforts focus on R\&D as one most dynamic, high prioritised and fast-growing sectors. Increasingly, the need for building centres supporting and mediating the symbiosis between higher education institutions (HEls) and business comes to the fore. Therefore, «innovation formations» are considered as open systems involving scientific, educational, research and production associations of private and public sectors (Kerchev, 2011). Herewith, the typology of systems mentioned above could be reduced to scientific, technological, high-tech and business parks (Ivanova, 2016). In turn, the cluster approach is used for their construction and work support emphasising on the integration of the efforts, collaboration and cooperation between the related organisations.

It creates a new labour reality, changes the requirements and brings out the need in highly qualified

Cite as: Raychev, S., Dimitrova, G., Madzhurova, B., \& Stoyanova, D. (2020). Innovations as a Factor for Economic Growth and Labor Market Development. Marketing and Management of Innovations, 3, 22-31. http://doi.org/10.21272/mmi.2020.3-02 

Development.

education, which leads to a rethinking the public policies for better accordance of skills and needs to the labour market, highlighting the need for cooperation with HEls. The summarisation of literary sources on the investigation the relationship between science and business in R\&D is a topic that is subject of researches by many scientists. On the one hand, there is interest in investigating the creation of innovations, their transfer to the economy and the subsequent commercialisation, while, on the other hand, the graduate employability. The collaboration between the three sides of the so-called «Knowledge triangle» - science («creator» of innovations), education («producer» of knowledge) and business (consumer of knowledge and innovation) is with increasing relevance and importance in a knowledgebased economy.

The above-mentioned is reflected in government policies, strategies, measures and programs concentrated on creating an environment that encourages the stable building relationship between university and business, in the context of concepts of the sustainable development, economic growth and competitiveness. The potential direction is promoting (also financing) R\&D and constructing research centres at universities.

Literature Review. On the one hand, research centres play an essential role in the creation of qualified scientific researches; on the other hand - encourage business to take part in research and innovation projects. It creates a favourable environment for knowledge and technology transfer, as well as the development and participation of enterprises in the international markets (Santos, 2017).

The enterprises are the other type of organisations that contribute to the development of innovation policies. The business helps to transform the acquired knowledge and education in new activities and products - innovation. Moreover, it provides closer collaboration in the scientific researches between universities and the industry. Industrial innovations stimulate economic growth and regional development, and they depend on the greatest extent on the amount of companies' investment in R\&D.

The empirical study proved that the investment in R\&D and the economic growth were positively related, where the strongest was the positive effect of the expenses in R\&D on the economic growth, especially in the high-tech sectors of countries with high levels of income per capita (Wang et al., 2013). However, the amount of the expenses in R\&D depends on the several company's characteristics and features as follows: company size, organisational structure, type of ownership, industrial branch and location. The imposed dependence is that the larger the companies are the greater tendency to invest in R\&D is (Shefer et al., 2005).

On the other hand, more significant investment in $R \& D$ is a prerequisite for stimulating high-tech exports, which contributes increasing gross domestic product (GDP) per capita or achieving economic growth (Ustabaş et al., 2016). Moreover, the statements show that in companies operating in highly competitive industries, innovations are highly developed (Weerawardena, et al.,2006). In turn, the business contributes to innovation development and competitiveness increase through its participation in the clusters.

Herewith, the clusters are considered to be the «geographical concentration of interconnected companies, specialised providers, service providers, companies from related industries and associated institutions that compete while cooperating» (Porter, 1998). It is a prerequisite for achieving a synergistic effect, increasing the efficiency of their teamwork and creating innovations in the processes and products offered by them. The interaction and cooperation between the structures of the interconnected research centres and enterprises is a necessary condition for achieving a qualified research, education and production process for the creation and distribution of R\&D, and from there attain sustainable growth.

The idea of the clusters has unabated research interest, in search of opportunities in conditions of globalised and growing competition. The cluster approach is based on the understanding of the favourable impact of the external conditions while emphasising on the local resources, which are cooperated to increase their competitiveness through teamwork and related activities.

The experience gained in the studies on the clusters (Rocha, Sternberg, 2005; Feldman et al., 2005; 

Development.

Velev, 2007, Delgadoa et al., 2014), helps to reveal different approaches to their creation, sustainability and development, and from there - to distinguish their main models - clusters of American, Asian and European types (Atanasova, 2014). In all the models, the relationship between universities (education and science) with business organisations could be brought out as structure-determining. The American model providing the focus on the intersectoral relations and integration, with the trend to regions, supports for regional innovation and the local economy. The participation of universities and country (Porter, 1998) is these processes are accepted as a leading element in the formation of clusters. In the Asian cluster model, universities also find their central place. The Japanese clusters are connected with country innovation system, while their focus is placed on the technological development and the construction of technology parks. They are characterised with specialisation and encouragement of the link between science, education and business through technology transfer. The Chinese clusters are formed on a sectoral basis, while the innovation clusters in the country are built around their leading universities. In the European model, clustering is supported by several EU policies and programs, which are echoed in the member states, particularly, Bulgaria. They are directed to national competitiveness (cluster development) to encourage cooperation between science, education and business through:

- support the development of science in Bulgaria for its transformation into a factor for economic growth, based on knowledge and innovation activities (National Strategy for Research Development 2020);

- building a sustainable education-science-business connection as a base for the development of a knowledge-based economy (Bulgaria 2020: National priorities in education and science);

- setting economic priorities with research and innovation activities, to create a competitive advantage by development and compliance of their strengths in the scientific researches with the needs of the industry (Innovation Strategy for Smart Specialization of the Republic of Bulgaria 2014-2020).

The connection between science and business is the subject of annual evaluation by several representative sources as follows: Global Competitiveness Report of the WEF, World Competitiveness Yearbook of the IMD, Global Innovation Index, The Global Economy, etc.

The globalisation processes and technological developments have posed new challenges to the world. Workplaces (Jobs) are changing, causing new requirements for employees. Along with the positive changes, there is also a threat of growing inequality. Governments face new challenges in managing public policies. One way to overcome inequality is a government policy in education, which leads to sustainable economic growth - increases welfare, reduces inequality and doesn't erode human capital. Education is the essential factor that could help the individual to overcome inequality in initial income (OECD,2018a). The new production technologies play an essential role in determining the availability, nature and quality of the jobs. The future labour market would generate exceptional opportunities for creating new and more productive jobs, but also risks to inclusive economic growth, as some skills become obsolete while others are in high demand. Moreover, the occupations are destroyed in some industries and regions, while others emerge elsewhere due to automation and digitalisation. Herewith, two technological trends above mentioned would affect future work and the requirements for business education, especially for overcoming inequalities. (OECD, 2018b). The countries' investing in high-qualified education would help Europe to achieve its economic and social goals. To meet the challenges of the new nature of jobs, the EU (EC, 2017) accepted recommendations aimed at investing in young people. Qualified education and high-tech skills are crucial for prospects and opportunities. It's recommended to emphasise the connection between learning and real-life experience, which raises the requirements of the relationship between higher education and business. Increasingly, skills acquisition is a continuum rather than a finite unchanging path. (WB, 2019).

It should be noted that between the quantity of HEls, education quality and the required workplaces is a gap. On the one hand, over-skilled workers have higher qualifications than typically needed from them at work. On the other hand, low-skilled workers are less skilled than those usually held by workers in their 

Development.

jobs. All these forms of non-compliance could have significant negative consequences for workers, causing a low level of job satisfaction. (Beduwe and Giret, 2011). The dissatisfied workers tend to move often in search of a better match between skills and work that could be followed by lower productivity due to their mental state and dissatisfaction.

The challenges also lie in «productivity connectivity» (OECD, 2016). Wage dispersion is thought to be related to productivity dispersion between the companies (Berlingieri et al., 2017), with globalisation and digitalisation strengthening this connection. Some characteristics of the digital economy that can lead to higher market concentration can potentially exacerbate this trend. Besides, the vast inequalities threaten future growth and productivity potential through low workforce participation, low employability and unsustainable economic growth. This phenomenon is also associated with a shrinking middle class, which is a source of great concern in several economies (OECD, 2017).

Over the past few decades, a «skills premium» has emerged in the labour market when more highly qualified, more educated people are better placed to take advantage of the productivity-enhancing technology involved in each type of the industry (CEB, 2017a).

The main statement from these data is the economic sustainability of people with higher education during the recent crisis, as opposed to those with less formal education. High-quality employment depends on an adequate education and training system that provides workers with the necessary skills and offers opportunities and incentives for learning throughout their working lives (CEB, 2017b).

The challenge for the public policies is to develop new tools for better compliance between skills and labour market needs and stable systems with tools to access and anticipate skills needs and make full use of the opportunities offered by new technologies.

Methodology and research methods. The subject of the present study is the dynamics of investments in innovations made by Bulgaria and EU28.

The research aim is deriving the position of Bulgaria in the world economy concerning $R \& D$ and reveal the dynamics of R\&D expenditures in Bulgaria and the EU28, through the prism of innovations from business and higher education, to encourage economic competitiveness and social welfare.

The author's thesis is that innovation activity and dynamics in R\&D expenditures have a leading role in stimulating cooperation between universities and business.

The main research methodology goal is to test the formulated hypothesis on the presence of dependence between labour market dynamics and the dynamics of indicators showing the economic and social growth of the economic system at the macro level through the prism of economic growth, competitiveness and inequality. This justification presupposes to examine the existence of interdependence and the causal connection between the selected indicators.

Using statistical tools when analysing the economic and social system, in particular - the labour market, has two main characteristics:

1) the logic and methodology of the applied statistics are used as the main part of statistical science, which is related to the practical application of statistics to social and economic problems;

2) due to the nature of issues investigated, the toolkit of economic statistics is used as a part of applied statistics, which focuses on the collection and analysis of economic data.

As the study of the research issues deals mainly with economic data, the methodology used includes the toolkit of both descriptiveness and statistics of conclusions. All statistical findings require the use of two main mechanisms - statistical assumptions and models.

In this sense, the research tasks of this analysis are:

1) make some theoretical remarks regarding the research centres and enterprises, cluster approach to increase competitiveness, where education is the principal way to overcome inequality;

2) make a description to derive the position of Bulgaria in the world economy concerning R\&D (from 2014 till 2019);

3) make a description of the Dynamics of R\&D expenditures in Bulgaria and the EU28 the period under 

Development.

review (2009-2018).

The used methods are as follows: processing of quantitative data, content analysis and comparative, situational and sectoral analyses, and graphical dynamic analysis. The approaches used are integration, system and cluster approach. The indicators that are studied are R\&D expenditure from the four main sectors defined in the national accounts system (public industries, business sectors, the private non-profit sector and high education sector) in BG and EU28 and.

The sources of data are as follows: The Global Competitiveness Report of the World Economic Forum (WEF), Eurostat, World Competitiveness Yearbook of the Institute for Governance Development (IMD), Global Innovation Index (GII), Global Economy.

Results. The Global Competitiveness Report of the World Economic Forum (WEF, 2014-2019) in 2019 put Bulgaria in 49th place in research and development (R\&D expenditures \% GDP), from a total of 141 countries. Data in Figure 1 show that in recent years the country has stabilised its position in this direction.

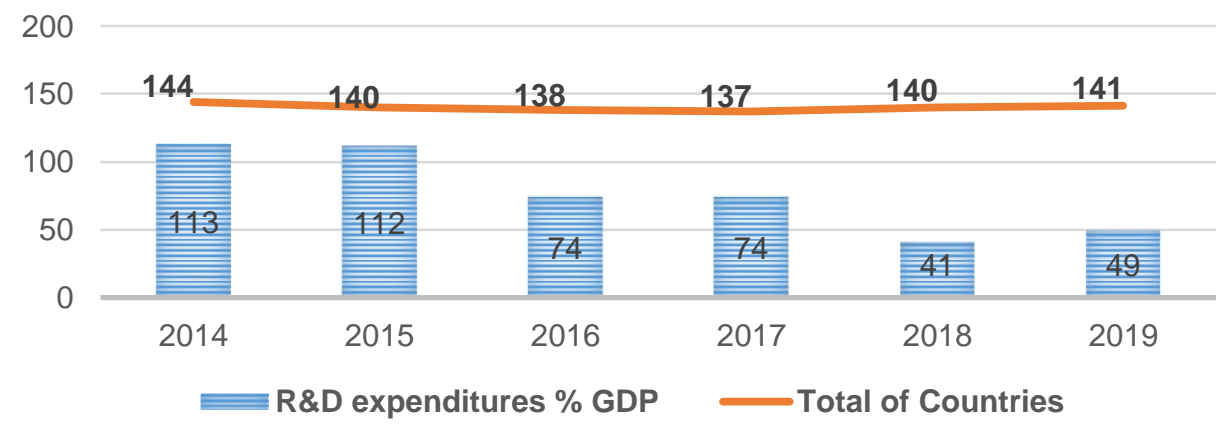

Figure 1. Position of Bulgaria - R\&D expenditures, 2014-2019 (\% to GDP)

Sources: Developed by the authors based on the Global Competitiveness Report (WEF, 2014-2019)

According to the World Competitiveness Yearbook of the Institute for Governance Development (IMD, 2019) out of total 63 countries the Bulgaria position in 2019 was as follows: in terms of education - 46th place, in terms of scientific infrastructure - 49th place.

The Global Innovation Index for 2019 shifted Bulgaria on 68th position in the education category and 51 st - in R\&D among a total of 129 countries.

In turn, by the Global Innovation Index for 2014-2019, the R\&D rank changes (Figure 2) from 61 to 51 (at 1 is the best), which it is an average position among the researched countries. The score changed by 11,7 (for 2019), where $100=\max$. strength, $0=\min$. strength. Moreover, it is an unsatisfactory position for Bulgaria (Global innovation index, 2014-2019). 
S., Raychev, G., Dimitrova, B., Madzhurova, D. Stoyanova. Innovations as a Factor for Economic Growth and Labor Market Development.

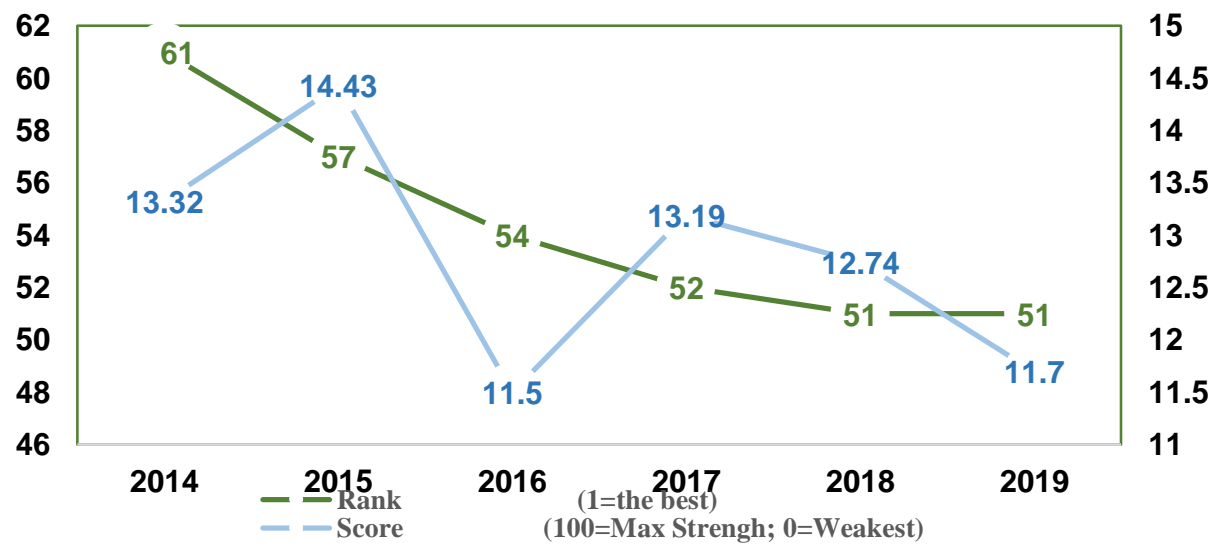

Figure 2. Bulgaria - R\&D, 2014-2019 (score, rank)

Source: Developed by the authors based on Knoema according to GII (Global innovation index, 2019)

Following the Global Economy data, Bulgaria's average value for 2010-2017 (Figure 3) was 0,70 per cent, while a minimum (0,53 per cent) was in 2011, and maximum (0,96 per cent) - in 2015. «The latest value from 2017 is 0.75 per cent. For comparison, the world average in 2017 based on 83 countries is 1,02 per cent» (Global Economy, 2010-2017)

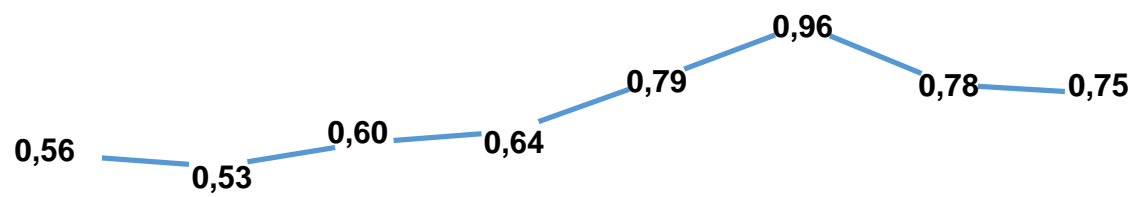

$\begin{array}{llllllll}2010 & 2011 & 2012 & 2013 & 2014 & 2015 & 2016 & 2017\end{array}$

Figure 3. Position of Bulgaria - R\&D expenditures, 2010-2017 (\% to GDP)

Source: Developed by the authors based on Global Economy (2010-2017), World Bank (2019).

Figure 4 presents R\&D expenditures of the main sectors as a percentage (per cent) of GDP of Bulgaria and the EU28 from 2009 to2018. Following the mentioned above, there are:

1) the difference between the sectors in the EU and Bulgaria in the R\&D expenditures during the studied period;

2) the difference between Bulgaria and the EU in terms of R\&D expenditures.

There is a growth in total R\&D expenditure rate from 1,93 in 2009 to 2,12 in 2018 in the EU. When analysing this change through the share dynamics of the sectors, the following was established:

- non-profit private sector R\&D expenditure remain unchanged at values about $0,02 \%$;

- R\&D expenditure incurred (performed, done) by the higher education sector varies between 0,46\% and $0,47 \%$; 
- public sector R\&D expenditure is clearly decreases by $0,26 \%$ in 2009 to $0,23 \%$ in 2018 ;

- R\&D expenditures performed by the business sector increase in the entire period from $1,19 \%$ in 2009 to $1,41 \%$ in 2018 .

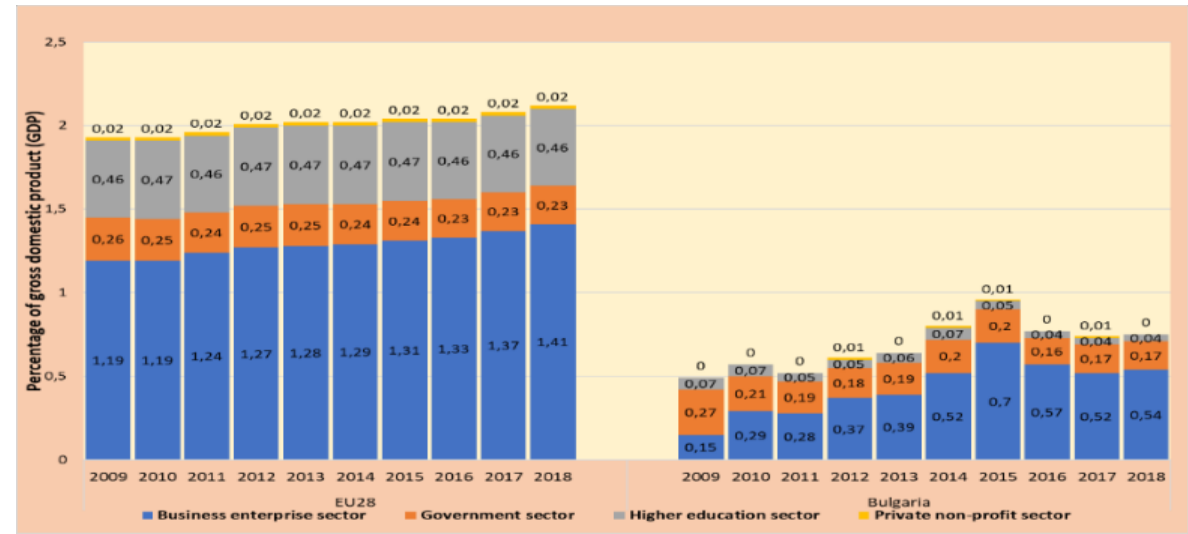

Figure 4. Gross domestic expenditure on R\&D by sectors of EU28 and Bulgaria, 2009-2018 (\% to GDP)

Source: Developed by the authors based on Eurostat data

From 2009 to 2018, the EU28 R\&D expenditures were steadily growing. Herewith, the expenditures on the business sector increased by $0,42 \%$, while the public sector decreased by $0,03 \%$. In turn, the total R\&D expenditure varies from $0,49 \%$ to $0,95 \%$ for the study period in Bulgaria. Moreover, the lowest value in 2009 was $0,49 \%$ and the highest $-0,95 \%$ in 2015 , while the decrease that reached $0,76 \%$ was in 2018 .

Unlike the EU28, there is no clear upward trend throughout the period. An analysis of this change through the share dynamics of the sectors demonstrated the following:

$-R \& D$ expenditures in Bulgaria;

- R\&D expenditures performed by the private non-profit sector remain unchanged at around $0,01 \%$;

- R\&D expenditure performed by the higher education sector varies between 0,04 and $0,07 \%$;

- public sector R\&D expenditures clearly decreased from $0,27 \%$ in 2009 to $0,17 \%$ in 2018 ;

$-R \& D$ expenditures performed by the business sector increased throughout the period from $0,15 \%$ in 2009 to $0,54 \%$ in 2018.

During the study period, R\&D expenditures in Bulgaria had been increasing by 2015, after that the decision was. Herewith, values remained higher than those in 2009. It should be emphasised that there were significant differences between the EU28 and Bulgaria as follows:

1) in the EU28 R\&D expenditures increased throughout the period, being the highest in 2018. In turn, in Bulgaria, the values in 2016-2018 were 0,2 (per cent points) lower than in 2015;

2) in Bulgaria all the sectors spent much less on R\&D expenditures as a per cent of GDP, compared to EU28. It worth noting that the expenditures values of the non-governmental sector $(0,02$ in the EU and 0,01 in Bulgaria) and the public sector (0,26 in the EU, 2009 and 0,27\% in Bulgaria, 2009) were very close, while expenditures in the other two sectors - higher education $(0,46 \%$ in the EU28, 2018 against $0,04 \%$ in Bulgaria, 2018) and the business sector (1,41\% in the EU28, 2018 against $0,54 \%$ in Bulgaria, 2018) was significantly different;

3) the share distribution of the sectors in the EU28 as a per cent of total R\&D expenditures showed that in 2018:

- the business sector constituted $66 \%$; 
- the public sector $-11 \%$;

- higher education sector - 22\%;

- the non-governmental sector $-1 \%$.

The share distribution in Bulgaria showed that in 2018:

- - the business sector constitutes $-71 \%$;

- - the public sector $-22 \%$;

- - higher education sector $-5 \%$;

- - the non-governmental sector $-1 \%$.

In the EU28 the business sector and higher education which constituted $88 \%$ of all the R\&D expenditures should be the engine (mover) for increasing economic growth and improving the well-being of society in a market economy. In Bulgaria, this part was 76\%. In the EU28, R\&D investment is much higher as a per cent of GDP and shows a continuous increase, while in Bulgaria, there is an increase compared to 2008 , but it is decrease compared to the middle of the period.

The difference in R\&D expenditures between the EU and Bulgaria not resulted from changes in the non-governmental and public sectors (although in Bulgaria the decrease was 0,1 per cent points, while in the EU28 it was only 0,03 ). It was due to large expenditures in the higher education sector and the business sector (although in Bulgaria the increase was 0,39 per cent points compared to 0,22 per cent points in the EU28). For catching up with the EU28, Bulgaria needs to stimulate much more the business sector to increase spending and investing in R\&D by 0,87 per cent points and the higher education sector by 0,42 per cent points, as well. Herewith, the most severe problem that Bulgaria faces is in higher education, indeed. If the expenditures of the business sector increase even at a slower rate than in the EU28, then the expenditures of the higher education sector are not only negligible small, they also fall from 0,07 to 0,04 per cent of GDP.

Conclusions. Conclusions. Undoubtedly, the cluster approach raises R\&D to a new level and helps to bring universities and business together. Rethinking of the public policies and investing in technology centres will help for the adaptation to the new realities of the labour market. It would facilitate the processes of knowledge and technology transfer, in the context of the implementation of scientific developments and innovations in the practical activities and employability of the graduating students. Education has already placed and considered through the processes of globalisation, and its fast adaptation is the only way to respond to technological change.

Author Contributions: For research articles with several authors, a short paragraph specifying their individual contributions must be provided. The following statements should be used conceptualisation, G. D, B. M, D. S; methodology, G. D, D. S, S. R; validation, G. D, B. M, D. S; formal analysis, G. D, B. M, D. S, investigation, G. D, B. M, D. S; resources, G. D, B. M, D. S; data curation, G. D, B. M, D. S; writingoriginal draft preparation, G. D, B. M, D. S; writing-review and editing, G. D, B. M, D. S; visualisation, G. D; supervision, G. D.

Funding: This research received no external funding.

\section{References}

Atanasova, A. (2014). Klasterna integratsia za povishavane konkurentosposobnostta na MSP, avtoreferat, Katedra «Menidzhmant i marketing», YuZU, Retrieved from: http://rd.swu.bg/media/35047/avtoreferat.pdf

Beduwe, C., \& Giret, J. F. (2011). Mismatch of vocational graduates: What penalty on French labour market?. Journal of vocational behavior, 78(1), 68-79. [Google Scholar] [CrossRef]

Berlingieri, G., Blanchenay, P., \& Criscuolo, C. (2017). The great divergence (s) (No. 83625). London School of Economics and Political Science, LSE Library. [Google Scholar] [CrossRef]

Bulgaria 2020: National priorities in education and science. Retrieved from: https://www.president.bg/docs/1352306046.pdf 
CEB. (2017) Educational inequality in Europe. Paris: Council of Europe Development Bank. Retrieved from https://coebank.org/media/documents/Part 2-Inequality-Education lowres.pdf

CEB. (2017) Investing in Public Infrastructure in Europe: A local economy perspective. Paris: Council of Europe Development Bank. Retrieved from https://coebank.org/media/documents/Investing in Public Infrastructure in Europe 27dc1 Pg.pdf

Delgado, M., Porter, M. E., \& Stern, S. (2014). Clusters, convergence, and economic performance. Research policy, 43(10), 1785-1799. [Google Scholar] [CrossRef]

EC. (2017). Uchilishtno razvitie i varhovi postizhenia v oblastta na prepodavaneto za po-dobar start v zhivota. Retrieved from https://eur-lex.europa.eu/summary/bg/4301065.

Feldman, M., Francis, J., \& Bercovitz, J. (2005). Creating a cluster while building a firm: Entrepreneurs and the formation of industrial clusters. Regional studies, 39(1), 129-141. [Google Scholar] [CrossRef]

Global Economy. (2017). Bulgaria: Research and development expenditure. Retrieved from https://www.theglobaleconomy.com/Bulgaria/Research and development/

Global innovation index 2019. Retrieved from https://knoema.ru/GII2018Aug/global-innovation-index-2019? country=1000290bulgaria\&accesskey=gveykrd

Global Innovation Index. (2019). The global innovation index (GII)2020: Who will Finance innovation? Retrieved from https://www.globalinnovationindex.org/Home

IMD. (2019). Countries profiles. Retrieved from https://www.imd.org/wcc/world-competitiveness-center-rankings/countries profiles/

Innovation strategy for intelligent specialisation of the Republic of Bulgaria (2014 - 2020). Retrieved from https://www.mi.government.bg/files/useruploads/files/innovations/ris3_18.12.2018_bulgarian.pdf

Ivanova, R. (2016). Science and technology perks as a structure for the development of innovation. Nauchni trudove na

Rusenskia universitet, 55.Retrieved from: http://conf.uni-ruse.bg/bg/docs/cp16/5.1/5.1-28.pdf.

Kerchev, Kr. (2011). Osnovi na inovatsionnata politika. Sofia, UI «Stopanstvo».

National Strategy for Development of Scientific Research in the Republic of Bulgaria 2017-2030. Retrieved from https://www.strategy.bg/StrategicDocuments/View.aspx?lang=bg-BG\&ld=1231

OECD. (2016). Productivity-Inclusiveness Nexus: Preliminary Version. Organisation for Economic Co-operation and Development. [CrossRef]

OECD. (2017). Science, Technology and Industry Policy Papers. Retrieved from https://www.oecd-library.org/science-andtechnology/the-great-divergence-s_953f3853-en

OECD. (2018a). Achieving inclusive growth in the face of digital transformation and the future of work. Retrieved from https://pdfs.semanticscholar.org/2c2a/0e7ece83eab0b49da19c1c52680400accc6c.pdf? ga=2.172668131.1795230168.15927079

62-530321094.1592707962

OECD. (2018b). Good Jobs for All in a Changing World of Work. Retrieved from http://www.oecd.org/employment/good-jobsfor-all-in-a-changing-world-of-work-9789264308817-en.htm

Porter, M. (1998). On Competition. Harvard Business School Publishing, Boston. Retrieved from http://ressources.aunege.fr/nuxeo/site/esupversions/ba0a40a7-4350-475d-a503-2475adcb9925/res/porter.pdf

Rocha, H. O., \& Sternberg, R. (2005). Entrepreneurship: The role of clusters theoretical perspectives and empirical evidence from Germany. Small Business Economics, 24(3), 267-292. [Google Scholar] [CrossRef]

Santos, J. (2017). A strategy to promote technology and knowledge transfer from research centers to the business enterprise sector. In 23rd Annual EARMA Conference, European Association of Research Managers and Administrators. [Google Scholar]

Shefer, D., \& Frenkel, A. (2005). R\&D, firm size and innovation: an empirical analysis. Technovation, 25(1), 25-32. [Google Scholar] [CrossRef]
The global
competitiveness
report
2019.
Retrieved
from

http://www3.weforum.org/docs/WEF TheGlobalCompetitivenessReport2019.pdf

Ustabaş, A., \& Ersin, Ö. Ö. (2016). The effects of R\&D and high technology exports on economic growth: A comparative cointegration analysis for Turkey and South Korea. In Proceedings from International Conference on Eurasian Economies (pp. 44-

55). [Google Scholar]

Velev, M. (2007). Cluster approach to increase competitiveness. Publishing House «Softreid».

Wang, D. H. M., Yu, T. H. K., \& Liu, H. Q. (2013). Heterogeneous effect of high-tech industrial R\&D spending on economic growth. Journal of Business Research, 66(10), 1990-1993. [Google Scholar] [CrossRef]

Weerawardena, J., O'Cass, A., \& Julian, C. (2006). Does industry matter? Examining the role of industry structure and organisational learning in innovation and brand performance. Journal of business research, 59(1), 37-45. [Google Scholar] [CrossRef]

World Bank. (2019). The changing nature of work. International Bank for Reconstruction and Development. Retrieved from https://data.worldbank.org/indicator/GB.XPD.RSDV.GD.ZS?end=2017\&locations=BG\&start=2010\&view=chart

Стефран Райчев, Ph.D., Пловдівський університет «Паїсій Хилендарський», Болгарія

Гергана Димитрова, Ph.D., Пловдівський університет «Паїсій Хилендарський», Болгарія

Блага Маджурова, Ph.D., Пловдівський університет «Паїсій Хилендарський», Болгарія

Добринка Стоянова, Ph.D., Пловдівський університет «Паїсій Хилендарський», Болгарія 
S., Raychev, G., Dimitrova, B., Madzhurova, D. Stoyanova. Innovations as a Factor for Economic Growth and Labor Market Development.

Інновації як фактор економічного зростання та розвитку ринку праці в країні

У статті проаналізовано та оцінено вплив науково-дослідних та дослідно-конструкторських робіт (НДДКР) як виду інновацій на рівень економічного розвитку країни. При цьому конкурентоспроможність оцінено такими параметрами: рівень конкурентоспроможності, фоннкціонування ринку праці та рівень нерівності в країні. Головною метою статті є визначення рівня розвитку НДДКР Болгарії у порівнянні з країнами-лідерами за рівнем інноваційного розвитку. Відповідно до мети дослідження авторами проведено порівняльний аналіз динаміки витрат на НДДКР у бізнес-секторі та освітній галузі на прикладі Болгарії та країн ЄС28. Результати систематизації наукових праць та підходів до вирішення досліджуваної проблематики засвідчили про наявність розривів між потребами ринку праці та кваліфікацією випускників закладів вищої освіти. Авторами зазначено, що стрімкий розвиток НДДКР спричинив зміни на ринку праці, що стало тригером до коригування освітніх програм. Методологію дослідження засновано на обробиі кількісних даних, змістовно-порівняльному, ситуаційно-галузевому та графрічно-динамічному аналізах. Об'єктом дослідження є динаміка інвестицій Болгарії та країн ЄС28, спрямованих ө інноваційний розвиток. У статті визначено та описано роль науково-дослідних центрів, підприємств, кластерів та закладів освіти у розвитку НДДКР на основі оиінювання досягнутого рівня інноваційного розвитку країни. Авторами наголошено про необхідність інвестиційної підтримки дослідницьких центрів з метою задоволення потреб ринку праці. За результатами емпіричного аналізу встановлено, що формування інноваційних кластерів дозволяє підвищити рівень ефективності НДДКР в країні, а також синхронізувати потреби бізнес-сектору та можливості системи освіти. Результати дослідження мають практичне значення і можуть бути корисними для роботодавців, представників закладів вищої освіти та наукових дослідницьких центрів. Очікується, що отриманні висновки стануть основою для подальщих досліджень, присвячених підвищенню конкурентоспроможності та соціального добробуту країни завдяки ї інноваційному розвитку.

Ключові слова: конкурентоспроможність, економічне зростання, нерівність, інновації, ринок праці, науково-дослідні та дослідно-конструкторські роботи (НДДКР).

Manuscript received: 12.02 .2020

(C) The author(s) 2020. This article is published with open access at Sumy State University 